\title{
Lastoŭski the Historian and his Historical Views
}

\author{
BY \\ V. SIENKIEVIČ
}

The Biełaruskaja Savieckaja Encyktapiedyja says the following about Łastoŭski the historian:

'Łastoŭski wrote several works dealing with the history of Byelorussia. His Karotkaja historyja Bietarusi was published in Vilna in 1910. His works are tendentious and offer a nationalist interpretation of historical facts. He was opposed to Marxism, rejecting the concept of class struggle and the leading role of the proletariat. In his opinion the national question predominated throughout history, and he therefore placed national interests above class interests; he drew a rigid distinction between Byelorussians and Russians, denied their common historical identity and actively propagated the notion of a "golden age" in Byelorussian history.'

The fifth volume of the Karotkaja Bietaruskaja Savieckaja Encykłapiedyja (Minsk, 1981) contains biographical details of people whose life and work is connected with Byelorussia, yet it can find no place whatsoever on any of its 720 pages for Lastoŭski. On the other hand space was found for 508 so-called 'heroes of socialist labour', i.e. milkmaids, pig-tenders, team-leaders, agricultural machine operators, brigade foremen and the like, not to mention 522 organizers and leaders of the Communist underground and partisan movement, 465 'heroes of the Soviet Union', about 60 holders of the 'Order of Glory' medal, and hundreds of other party and government functionaries who in fact never had any direct dealings with Byelorussia. No space was found for the man about whom Janka Kupała, the prophet of the Byelorussian national renaissance, wrote:

'Na kurhanie, na adviečnym,

Pad asinaj viekavoj,

Sieŭ Dudar, sahnuŭšy plečy,

$\mathrm{Z}$ pasiviełaj hałavoj.

$\mathrm{Na}$ dudzie, na samahudzie,

(A duda - jak vieča zvon),

Ducham klič puskaje ŭ ludzi -

Pieśnia ŭ pieśniu, ton $u$ ton.

I ŭ budučyniu hlanie

Dumkaj pieśnia Dudara,

Źniapryvyčnym zapytańniem:

Ci pračnucca nie para? 
Tак daŭno ŭ nas nia jhrali,

Dziŭ adno płyvie i čar,

Sto raz vyšaj, sto raz dalej, -

Znać byvały jon Dudar.

Staraśviecki jon muzyka,

Važna tołk viadzie ŭ dudzie,

Važna dolaju vialikaj

I svabodaju hudzie...'

(from Dudar) $)^{2}$

In another of his poems - Pieśnia zvanara (The Herald's Song) of 1909 ('herald' was Kupała's apt description of Lastoŭski) — the poet sings of Vłast, the author of the wonderful Labirynty:

'Razhudzicca moj zvon ad vakon da vakon,

Dušy zbudzić, pa sercach udara,

Drohnuć schovy ciamnic, blisnuć iskry zarnic,

Zavarušacca jary, papary.

Na moj klič viečavy, chto žyvy, čuć žyvy,

Pad haroju kasoj zahamonie.

Hułam zvona skažu, ściežku-šlach pakažu

Na pryvolle, na ŭrodnyja honi!

Za haroj, za druhoj dam žyvy vadapoj,

Žyvatvornaje kožnamu zielle;

$\mathrm{Na}$ niaźličany čas pa niahodach papas

Usim tym, što ciarpiać i ciarpieli.

Hetki budzie moj klik — i mahuč i vialik,

A nia trapić jon $\mathrm{k}$ dušam praspanym, -

Vyzvu hrom, piaruny - chaj pamohuć jany

Razvahnić, zatraści ŭsie palany...

As we can see, for Janka Kupała, himself the prophet of the Byelorussian national renaissance, Vacłaŭ Lastoŭski was unquestionably the 'herald' of that reawakening. This apt description of Łastoŭski was used by the Byelorussian author R. Sklut (Professor A. Adamovič) as the title of his fascinating and unique study of Lastoŭski which appeared in 1954 in issues of the newspaper Backaǔšcyna. ${ }^{4}$ As 'herald of the national rebirth' Łastoŭski was statesman, actual editor of Naša niva, poet, writer, literary critic, journalist, bibliographer, politician, ethnographer, historian. He may not have been a specialist in any one of these areas, but he made a significant contribution to each of them. It was in historiography that he broke important new ground; he performed a truly pioneering task by examining the history of his native country in a completely new way. He cleared away the falsehoods clinging to Byelorussian history and thereby exerted an enormous influence on Kupała and other Byelorussian poets in that they became more keenly aware of historical subjects. As we shall see later, Łastoŭski drew attention to the crucial importance of terminology, without which the rich ancient heritage of the Byelorussian nation can- 
not be understood. He was the first Byelorussian to raise the question of the origin of the Byelorussian nation and particularly of 'Litva'.

Without doubt Byelorussian national historiography began in 1910, the year in which Vłast's (Łastoŭski's) Karotkaja historyja Biełarusi was printed on Marcin Kuchta's presses in Vilna. It was the first history of Byelorussia to be written in Byelorussian and to explore the country's past in a way that set it quite apart both from official tsarist handbooks and from the work of Polish scholars. It laid the foundations for the writing of Byelorussian history and its author thereby became the first Byelorussian national historian. Just how it was that the honour of being the first in the field fell to him is described in Sklut's 'Zvanar Adradžeńnia':

'One of the primary tasks which Łastoŭski had to take upon himself in the Naša niva renaissance was that of national historian, or rather, of the first Byelorussian to write the history of his country. The importance of a knowledge of history and of spreading that knowledge among the masses of people who were only just beginning to acquire a sense of their national identity was something not completely understood by the pioneers of the Naša niva movement. Naša niva was reaching a mature stage of development and yet the whole question of history had not even been broached. The antiquarian and archaeologist Ivan Luckievič was the one most capable of performing the task because of his university training in archaeology, but unfortunately he showed no inclination towards writing during his short lifetime. So it was that the entirely self-taught Łastoŭski, out of a love for the "glorious past" of his country "reread the little historical literature that had formed part of (his) self-education and, most importantly, became imbued with a lofty sense of duty to awaken the national spirit".'

The Biełaruskaja Savieckaja Encykłapiedyja makes no mention of the fact that several generations of Byelorussian schoolchildren studied their country's history from Łastoŭski's Karotkaja historyja Biełarusi; it was the standard textbook on the subject in Soviet Byelorussia until the second half of the 1920s.

Fully aware of the importance of a knowledge of history for awakening the national spirit, Łastoŭski writes in the preface:

'History is the foundation on which the life of any nation is built. If we are to build our life anew, we must begin with the foundations so that the building will stand firm... Our foundations are impressive and our history rich. "The harvest is plenteous, but the labourers are few", as it says in the Gospels. The field is empty because the sons of our country have hired themselves to foreigners and are now enriching foreign barns and storehouses! ${ }^{7}$

At the time when the book appeared, these bold words were of vital relevance. The national spiritual rebirth of the Byelorussian people was only just beginning; the nation was enslaved and for the most part illiterate. Only a handful of people devoted themselves to the task of national regeneration and grouped themselves around the newspaper Naša niva. This process of regeneration required first and foremost en- 
thusiastic young people with an awareness of the nation's past. For this reason Lastoŭski writes in the preface:

'I dedicate this work to the sons of young Byelorussia, so that even from this short and incomplete book they may discover in their own language the history of their native country. For scholars the book contains nothing new; everything that is in it can be found scattered in the works of other authors, of which a list is provided below (indeed, Łastoŭski lists 18 different works in Russian and Polish - VS). I permitted myself one liberty only - that of evaluating certain events in my own way according to the benefit or harm they brought to the Byelorussian people. ${ }^{8}$

The Karotkaja historyja Bietarusi is indeed not a work of individual research, but a compilation from various sources. The author himself confirms this in the preface:

'When I undertook the task of writing this short account of our history, I did not have the ability to produce a work of scholarship resulting from a long period of research. I wrote what I could - bringing together what I knew about the history of our country and nation from Russian, Polish and Ukrainian historians, and putting it all in order in such a way that every event should come to life. ${ }^{9}$

Łastoŭski could not have done otherwise, for, as has been said already, he not only was not a historian, but had not even had any formal higher education; he was, like Janka Kupała, self-taught, but naturally very talented and extremely hard-working, as is demonstrated by the wealth of scholarly and literary work that he produced in his lifetime.

A systematic description or comprehensive evaluation of events should not be sought in this book. Many facts are missing without which a full understanding of Byelorussia's past is impossible. For example Łastoŭski fails to mention either Francis Skaryna or Kastuś Kalinoŭski. He wrote about Kalinoŭski for the first time in the article 'Pamiaci Spraviadlivaha' which first appeared in Homan and was later reprinted in the 1919 issue of the calendar Svajak. In his book Łastoŭski portrays the history of Byelorussia primarily as a chronicle of ruling princes, political and religious wars; cultural events are only partially dealt with, and economic and social problems are omitted entirely. This is, however, beside the point. If we bear in mind the time and conditions in which the book was written, then we can see that it was a tremendous achievement.

The most important aspect of the book is that Łastoŭski in several instances looks at the past of Byelorussia in a completely new way, portraying it not only as an historical object, always dependant on its neighbours, but as an historical subject, ruling itself and creating its own cultural values.

Right at the very end of the book Lastoŭski writes:

'In finishing this short survey of our country's history, let us once more glance back into the distant past and take a look at our nation's cultural development. Learning began to spread after the adoption of Christianity, not only among the princes and clergy, but even reaching down to "simple" folk... In the 12th century Byelorussian culture stood very high. 
From that time it continued to develop, so that when Byelorussia joined in union with Lithuania, the Lithuanians, having no culture of their own, adopted Byelorussian culture. The Old Byelorussian language was for Lithuania what Polish is today for our lords: princes and noblemen spoke it, it was the language of state documents and the courts; diplomatic relations were conducted in Byelorussian, laws were written in it. And so it remained until the 17 th century.'

These words of Lastoŭski's are very reminiscent of lines from Kupała's poem Nad Niomnam:
'Kraj, dzie žyćcio ja svajo pačynaju,
Šmat viesialej pryhladaŭsia na śviet,
Pieśni i kazki inakšyja baiŭ,
Ščaście ćviło ŭ im, jak makavy ćviet.
Bujnym žyćciom usio čysta kipieła,
Słava daloka za mora išła.
Voraha kožny za plečy braŭ śmieła,
Ciemra čužyncaŭ nia strašnaj była.
Panam byŭ doma i słaŭnym za domam
Moj pataptany siahońnia narod;
Zmoh jon nia tolki znać štuki z zatomam,
Rodnamu słovu ŭmieŭ knižny dać chod...

I have devoted considerable attention to Łastoŭski's Karotkaja historyja Bietarusi precisely because it laid the foundations for Byelorussian national historiography by looking afresh at the country's past. In his later works Łastoŭski developed and extended his views of the history of Byelorussia, and through his literary work on historical themes influenced others who were actively trying to restore a sense of national identity to the Byelorussian people. We can trace this development from the Pieršaja čytanka of 1915 (in which Łastoŭski for the first time published short stories and poems, mostly of his own composition, on Byelorussia's past and its greatest heroes - Usiasłaŭ the magician, Vitaut the Great and others) to later readers like Niadzielka, Rodnyja zierniaty, Siajbit, and especially the journal Kryvič.

As the first Byelorussian national historian, Łastoŭski well knew that the country had a rich ancient heritage. At the same time he realized that a large part of this heritage lay beneath unexplained historical terms like 'ruski', 'litoŭski', etc., and that confusion in terminology leads to the distortion of the whole process of development of the Byelorussian people, and to the suppression of its history. He therefore made the first attempts to interpret these terms; the result was two articles: 'Ab najmieńniach "Gudy", "Kryvičy", "Ruś", and 'Što takoje "Ruś" smalenskaj tarhovaj hramaty 1229 hodu'. The first article, which Łastoŭski signed with the pseudonym Jury Vieraščaka, appeared in the first issue of Kryvic for 1923; the second, signed by the cryptonym L. A., was published in the sixth issue of the same year.

Łastoŭski opens "Ab najmieńniach "Gudy", "Kryvičy", "Ruś"' with 
the general statement that 'no nation has been called by the same name throughout its history. Under the influence of migrations... foreign conquests, changes in the ruling dynasty or religion, the establishment of new national centres and other similar causes, changes have been made to the names of nations and of states'.

He firstly investigates the term 'Gudaj', which is used to this day by Lithuanians to refer to Byelorussians. This is followed by a consideration of the word 'kreevu', still used by Letts to refer to Byelorussians. Łastoŭski then turns his attention to the chronicles, firstly citing Nestor's Povest' vremennych let to demonstrate the rise and increasing use of the terms 'Ruś', 'ruski' on Byelorussian territory. He writes:

"The term "Ruś" spread over the territory of the Krivičy not because of the ruling dynasty, but as a result of the spread of Christianity. The adoption of Christianity by Grand Duke Vladimir of Kiev had important consequences for the Rus rulers and their followers. The level of literacy among their Slav subjects brought about the assimilation of the rulers (just as had happened in Bulgaria) and the adoption of their subjects' language. In turn Christianity, at first the faith of the ruling classes, of the princes and their followers, the faith of the Rus, came to be called "ruskaja vera" (the Rus faith). The terms "Rus" and "chryścianin" came to mean the same thing. The subjugation of the Slavs by the Varangians was concealed beneath the lofty aim of spreading the "Rus faith", i.e. Christianity. The fact that the Kievan Rus held the monopoly of Christianity played an important role in establishing their authority and extending their influence. They now had on their side the Christian Church with its organization and literacy; in addition the "divinely protected" city of Kiev became the centre of the Church. Christianity, which had already taken root among the urban population of the east Slavonic territory, soon began to spread. After 200 years the whole of this territory had become Christian and had acquired the name Ruś. The old tribal and state names fell into disrepute as remnants of a vanquished pagan era, backward and uncultured. The Kryvičy also adopted the name "Ruś" in this transitional period between paganism and Christianity. However, the old name "Kryvičy" did not yield to the new name immediately because it was so well established. We have already seen that in the 11th century the Kievan chronicler did not include the Kryvičy in Ruś. To this day the Letts call us not "Biełarusy" but "Kryvičy" (Kreevu). This same term was used until recently in statistical compilations (e.g. in Stolpjanski's Deviat' gubernij Zapadnogo Kraja, publ. in 1866) and is preserved in the folk memory as the name of our nation.

From this it follows that: a) the term "Ruś" is not of Slavonic origin but was brought to the Slavonic lands by the Normans in the 9th century; b) increasing use was made of it by the Slavonic tribes to refer to the ruling dynasty, and especially to those confessing a particular religion. In this latter sense it became established among the Kryvičy as well.' ${ }^{12}$

Here then was Łastoŭski's original view of the way in which the terms 'Ruś', 'ruski' were brought to the Byelorussian lands. It should be pointed out that his interpretation of the religious significance contained in these words as an important factor in transmitting them from Kiev to the whole expanse of territory occupied by the eastern Slavs 
found confirmation some thirty years later in an investigation of primary source material by the Polish historian Henryk Paszkiewicz. ${ }^{13}$ The Ukrainian historian Hrycak was the first to point out the connection, in his review of Paszkiewicz's book; ${ }^{14}$ he was followed by the Byelorussian historian Zaprudnik.

In 1963 Paszkiewicz published a second book, ${ }^{16}$ in which he formulated more precisely and in greater depth the views expressed in the first one. He also turned his attention to specific criticisms that had been levelled at it, and recognized that his interpretation of the term 'Ruś' had already been made earlier by 'White Russian scholars'. In answering the objections of Jakobson that his work allegedly adopts a hostile stance towards Poland's eastern neighbours and attempts to diminish the value of their cultures, Paszkiewicz writes:

'Jakobson criticizes the chief thesis of (the book) The Origin of Russia regarding the ecclesiastical and religious significance of the term "Ruś" and sees in it an instance of my political, polonophile tendencies. Now, it must be stressed that the same interpretation of the meaning of Rus was formulated by White Russian scholars. Thus, Jakobson's assertions are also directed against them. Where is then my depreciation of Poland's eastern neighbours?"'

As Zaprudnik has aptly pointed out, ${ }^{18}$ Paszkiewicz recognized that 'White Russian scholars' had already put forward a view which was fundamental to the conclusions of his own book (relating to the method whereby the term 'Ruś' spread from Kiev) but did not in fact know that there was only one 'White Russian scholar' concerned, since both Jury Vieraščaka and L. A. were actually Vacłaŭ Łastoŭski.

Although Łastoŭski's view of the way in which 'Ruś' and 'ruski' came to refer to the Byelorussian lands is in essence identical to that of Paszkiewicz, there are nevertheless some slight differences in formulation. Łastoŭski says that the term 'Ruś' was increasingly used 'by the Slavonic tribes to refer to the ruling dynasty, and especially to those confessing a particular religion'; Paszkiewicz puts the same thought in the following way:

'In historical terms, the word "Ruś" had a double meaning. Geographically and politically it designated Kiev with the adjacent territories, while in the religious sense it included all Slavonic and non-Slavonic followers of the faith of Rus. The individual provinces - Novgorod, Polotsk, Smolensk, Volynia, Halicz, etc. - were not comprised under the term 'Ruś', but were, on the contrary, often contrasted with it. Yet they belonged to Ruś in the religious sense. This fact indicates that it was not the dynasty founded by Rurik, but the Eastern Church which was the chief propagator of the name of Ruś in eastern Europe. Indeed, the Kievan state lost much of its strength after the days of Vladimir and Yaroslav - that is, after the middle of the 11th century. ${ }^{19}$

Łastoŭski talks of Ruś only in the dynastic sense, whereas PaszkiewXZ icz underlines its broader meaning in pointing to its geographical and political significance. Łastoŭski restricts the ecclesiastical use of the word 'Ruś' to the east Slavonic territories; Paszkiewicz, on the other hand, gives a wider definition to the word by saying that 'in the re- 
ligious sense it included all Slavonic and non-Slavonic followers of the faith of Rus, i.e. of the Orthodox faith. This modification 'is both important and historically valid; the Slavonicization of the Finnish tribes began precisely with their conversion to the "Rus faith". Then followed Russification'. ${ }^{20}$

The second article, 'Što takoje "Ruś" smalenskaj tarhovaj hramaty 1229 hodu', develops the ideas of the previous one. Lastoŭski draws attention to the fact that in the text of the treaty the German merchants of Riga and Gotland are always referred to as 'Latins', and the Smolensk merchants as 'Ruś'. 'Ruś' is clearly contrasted with 'Latins', a word with obvious religious connotations. He writes:

'As can be seen from the Smolensk trade treaty of 1229, and more generally from all the treaties concluded between the Germans and the Kryvič cities of Smolensk, Viciebsk and Połack, the inhabitants of these cities are referred to with the words "Ruś", "ruski", "rusin". Just what do these words mean exactly? Do they refer to a state, or to a tribe, or to both together? In actual fact the documents show us that the term "Ruś" was used by the compilers in quite another sense.

Two terms are used to refer to the German side in the documents: "nemci" (Germans) and "latines'kii" (Latin). The first of these words is of course still used nowadays as the name of the German nation, and is used exclusively with that meaning. Earlier, however, it had two meanings: a) a foreigner, someone speaking a different language and therefore impossible to talk with, and b) someone of the Latin (Catholic) rite. In the documents under discussion the words "nemeckii" and "latines'kii" are used as synonyms, e.g. "u nemeckoi božnicy", "u latines'koi cerkvi". This is completely in accord with historical facts. The words "nemec" "nemeckaja vera" were used in this sense in Byelorussia up to the 15th century, as can be seen from the chronicles. Not infrequently the only representatives of the Roman Catholic rite at that time in Byelorussia were merchants from German cities.

The word "latines'kii" is perfectly clear; it refers to the Latin faith. The trade treaties and documents of the cities mentioned above use "latines'kii" much more frequently than "nemeckii" which is used relatively rarely.

It can be justifiably concluded from this that the representatives of the Hansa cities, when concluding treaties with Byelorussian cities, possessed one unifying factor - religion. In this particular example the representatives of Riga were not Germans by nationality but professed the Latin rite and were therefore referred to here and there as "Germans".

The question then arises - if one side is referred to consistently by terms with religious meaning, then according to the laws of logic the other side ought to be referred to with a corresponding term denoting a unifying religion. Only in this sense will the terms "latines'kii" and "rusin", standing side by side, be natural and intelligible. If one side were to denote itself by a religious term, and the other, in contrast, by its own ethnographical name, then surely such inconsistency would be absurd in an important document of this nature. ${ }^{21}$

Łastoŭski notes that the use of terms denoting religious affinity was 
perfectly in accord with the concepts of the time, and draws the following conclusion:

'On this basis the terms "latines'kii" and "ruski" were both used in the same way, because they both emphasize the religious affiliations of the sides concluding the agreement. The trade treaties of the 13th-15th centuries therefore provide yet further proof that the word "Ruś" was used and understood not in an ethnographical, but in a religious sense. ${ }^{22}$

As we can see, Łastoŭski discusses his interpretation of 'Ruś' briefly and laconically, and demonstrates its correctness with a small number of examples taken from chronicles and documents. Paszkiewicz supports the same interpretation by means of a wealth of source material, making it the very foundation of his work.

Zaprudnik puts it very succinctly:

'However thoroughly this subject is researched, whether now or in the future, by Paszkiewicz or other scholars, it is a fact that such research will be no more than an elaboration of the historical ideas and original thoughts already propounded by the Byelorussian historian Vacłaŭ Łastoŭski.

But Łastoŭski was interested in more than the words 'Ruś', 'ruski'. He was well aware that much of Byelorussia's past lay hidden beneath other terms, especially 'Litva'. He was the first Byelorussian to raise the question of the origin of this word, ${ }^{24}$ firstly in Naša niva, ${ }^{25}$ and a little later in Knižyca dla školnaha čytańnia: Rodnyja zierniaty, published in 1916. Łastoŭski adopted the well-known theory of the Czech scholar Šafaryk, who identified historical Lithuania with the Slavonic tribes of the Lutiči (Volaty, Vaŭki-Vil'ki), and wrote the following in an essay about Vilna:

'A people once lived here... Who exactly were they? Of what tribe or nation? History has as yet given us no answer to this question. Some think that they were Slavs, of the tribe from which arose the Byelorussian people. Their name was written variously at different times by different people. Some called them Volaty, Velety, Vaŭki, others called them by the epithet "ljutyje" in the positive sense of 'brave, bold, daring'. The tribe of the Volaty or Velety lived between the Dniepr, Biarezina and Western Dvina rivers. It founded the Grand Duchy of Lithuania and died out, leaving only burial-mounds and place-names, such as Vałatoŭka, Vołatava słabada, Vołatava mahiła, Vołatava haradzišča, etc. The epithet applied to them, Ljuty, gave rise to the state name Litva by passing through several stages: Ljuty, Ljutvik, Ljutvjak — Lic'vjak; Ljuty, Ljutvin - Litvin. ${ }^{26}$

As Sklut says:

'Łastoŭski does not follow Šafaryk in linking "Litva" with the historically known but extinct west Slavonic tribes of the Volaty and Ljucičy, but attempts to find a simpler route by deriving Litva directly from the tribal epithet "ljuty".'2

Later Łastoŭski wished to return to this theory and intended to place it on a firmer scientific foundation by using archaeological data; however, he was arrested and his plans were never realized. Other scholars 
did take up the theme, e.g. Jazep Losik, the Paris-based Bietaruskija naviny, and to some extent, Vacłaŭ Panucevič. It would not be surprising if the theory were to be reexamined in the future. The main point in all this is that Lastoŭski was the first Byelorussian to work towards a solution of the problem of the origin of 'Litva'.

Once inside the terminological maze of Byelorussia's past Lastoŭski realized that the logical conclusion of the whole process of Byelorussian national self-determination and assertion of national individuality must be independence, for which a proper national name is essential. He sought and, as it seemed to him, found one: the historical name 'Kryvičy':

'At a time when our nation is struggling to regenerate itself from its very roots, and is seeking its identity in language, customs, art and literature, it is important that it should be reminded of its own name, a name moreover that speaks of the better days of the past, with free popular assemblies and glorious struggles for independence. This name should emphasize to the nation that it is not merely a variety of someone else's identity, but has an identity of its own. ${ }^{28}$

Elsewhere he poses the problem even more directly:

'My desire to restore the name "Kryvičy" to its rightful place stems logically from my understanding of the national renaissance movement, which must rely on our historical past and the individual character of our nation, not on Russian russificatory traditions. ${ }^{29}$

Łastoŭski's efforts to reinstate the word 'Kryvičy' had more than mere antiquarian significance. As Sklut has rightly observed, the word acquired a particular importance for speeding the process of national self-determination in the future, and for representing the nation abroad. As a politician who had been active in the international arena Łastoŭski knew full well what it meant to speak of 'Byelorussians'. ${ }^{30}$ He wrote in Kryvičy:

'As "Byelorussians" we are only a reflection of some all-Russian entity, some kind of "poor man's Russian", but as "Kryvičy" we assume an identity of our own, that of a distinct Slavonic tribe with a rich history, our own language, territory and culture. Sound logic, history, the interests and traditions of our renaissance all tell us that we have been known by three names: Kryvičy, Ruś (Bielaruś), Litva, but only the first of these is proper to us. We do not reject the names that we have acquired in the course of our history, but we certainly do not have the right to reject the name by which we called ourselves when we first entered the historical arena, the name which emphasizes our national identity and therefore guarantees our separate existence in the future... ${ }^{13}$

To quote the Bielaruskaja Savieckaja Encyklapiedyja once again, Łastoŭski 'placed national interests above class interests'. Even if we cannot agree with other assertions of the Encyclopedia, we can certainly agree with this one. As the herald of Byelorussian national rebirth he could not be considered in any other way. He laid the foundations of Byelorussian national historiography, he took a fresh look at the past of his country, he cleared away the lies clinging to Byelorussian history, he was the first to realize the crucial importance of deci- 
phering historical terminology, without which no understanding of Byelorussia's rich and ancient heritage would be possible, and he was the first to seek a proper name for the Byelorussian people. Byelorussians will be ever grateful to him for his work.

\section{NOTES}

1. Biełaruskaja Savieckaja Encyklapiedyja, vol. 6, Minsk, 1972, p. 267.

2. Janka Kupała, Spadčyna, New York - Munich, 1955, pp. 105-6.

3. ibid., pp. 106-7.

4. R. Sklut, 'Zvanar Adradžeńnia (Vacłaŭ Łastoŭski)', Backaǔščyna, nos 7 (189) - 1516 (197-198), 18 (200) - 20-21 (202-203), 1954.

5. Vłast, Karotkaja historyja Biełarusi (z sarakami rysunkami), Vilna, 1910.

6. Sklut, op. cit., 12-13 (194-195), p. 3.

7. Vłast, op. cit., p. iii.

8. ibid.

9. ibid.

10. ibid., pp. 92-3.

11. Kupała, op. cit., pp. 72-3.

12. Ju. Vieraščaka, 'Ab najmieńniach "Gudy", "Kryvičy", "Ruś"', Kryvič, no. 1. 1923, pp. 17-24.

13. H. Paszkiewicz, The Origin of Russia, London, 1954.

14. P. Hrycak, in The Ukrainian Quarterly, New York, 1955. p. 181.

15. J. Zaprudnik, Histaryčnyja kancepcyi Łastoŭskaha ŭ raspracavańni sučasnych historykaŭ, typescript, s.a.

16. Paszkiewicz, The Making of the Russian Nation, London, 1963.

17. ibid., p. 325.

18. Zaprudnik, op. cit., p. 5.

19. Paszkiewicz, The Making of the Russian Nation, p. 146.

20. Zaprudnik, op. cit.

21. L. A., 'Što takoje "Ruś" smalenskaj tarhovaj hramaty 1229 hodu', Kryvič. no. 6. 1923, pp. 23-4.

22. ibid., p. 24.

23. Zaprudnik, op. cit., p. 9.

24. Sklut, op. cit., no. 12-13 (194-195), p. 3.

25. cf. Sklut, ibid.

26. Rodnyja zierniaty, Vilna, 1916, p. 186.

27. Sklut, op. cit., no. 12-13 (194-195), p. 3.

28. Kryvič, no. $10 / 2,1925$, pp. 44-5.

29. ibid.

30. Sklut, op. cit., no. 36-37 (218-219), p. 2.

31. Kryvič, no. $10 / 2$, 1925 , pp. 45-6. 